\title{
REGIONÁLNÍ INOVAČNÍ STRATEGIE A JEJICH FINANCOVÁNÍ
}

\section{REGIONAL INNOVATION STRATEGIES AND ITS FINANCING}

\author{
ING. BARBORA BABJAKOVÁ, PHD. ${ }^{1}$ \\ ING. PETR JIŘÍČEK ${ }^{2}$
}

\author{
${ }^{1}$ Katedra regionalistiky a rozvoja vidieka ${ }^{1}$ Department of Regional and Rural Studies \\ Fakulta európskych štúdii a regionálneho rozvoja Faculty of European Studies and Regional Develop. \\ Slovenská polnohospodárska univerzita v Nitre Slovak University of Agriculture in Nitra \\ $\triangle \operatorname{Tr}$. A. Hlinku 2, 94901 Nitra, Slovak Republic \\ E-mail: barbora.babjakova@uniag.sk \\ ${ }^{2}$ Katedra ekonomických studii $\mid{ }^{2}$ Department of Economic Studies \\ Vysoká škola polytechnická Jihlava $\mid$ College of Polytechnics Jihlava \\ $\bowtie$ Tolstého 16, 58601 Jihlava, Czech Republic \\ E-mail:petr.jiricek@vspj.cz
}

\begin{abstract}
Anotace
Znalostni ekonomika je postavena na inovacich a znalostech, které vytvářeji vysokou přidanou hodnotu a umožňuji ekonomický růst. V regionálni dimenzi je proto velice důležité zaměrit se na regionálni podporu vytvárení, zaváděni a diseminace inovaci v regionu, čím se zvyšuje jeho konkurenceschopnost. Plánování takové podpory je deklarováno v regionálních inovačnich strategiich, které představuji koordinováni rozvoje v oblasti znalostni ekonomiky. Článek se zaměruje právě na komparaci regionálních inovačnich strategií v České a Slovenské republice ve vybraných regionech, které vytvárejí různé podmínky pro rozvoj znalostni ekonomiky. I když je možné pozorovat určitou podobnost mezi strategiemi, strategie jsou rozdilné v závislosti od zpracovateli strategie, od předešlých zkušeností, v menši míre od hospodářského zaměreni regionu.
\end{abstract}

\section{Klíčová slova}

inovace, znalostni ekonomika, inovační strategie, EIS, financování

\section{Annotation}

Knowledge based economy is based on innovations and knowledge creating high added value and enabling high economic growth. Therefore, it is important in regional dimension to focus on regional support of creation, introduction and dissemination of innovations in region to increase his competitiveness. Planning of such interventions is declared in regional innovation strategies presenting the coordinating of the development in the field of knowledge based economy. The paper is oriented on the comparison of regional innovation strategies in Czech and Slovak Republic in chosen regions which create different conditions for knowledge economy development. Even though it is possible to observe the similarity to some extent, strategies are different dependently on the participating stakeholders, previous experiences, to the lesser extent on the economic specialization of the region.

\section{Key words}

innovation, knowledge economy, innovation strategy, EIS, financing

JEL classification: $R 58$ 


\section{Úvod}

Př́spěvek se zabývá koncepčními dokumenty, vytvářenými na regionální úrovni s cílem zvýšit inovační potenciál regionu, tj. dosažení vyšší úrovně inovací oproti současnému stavu a zlepšení předpoklady pro další ekonomický rozvoj regionu a finančními nástroji, jež mají umožnit podporu inovací v daném regionu. Projevem sebeuvědomění existence regionů v oblasti ekonomické, sociální, environmentální a kulturně-historické od vzniku regionální správy v České republice i na Slovensku byl vznik nejrůznějších strategických analýz a koncepcí, odrážejících prostorovou i časovou stránku regionálního rozvoje a utvářel se proces uvědomování si regionálních disparit. Bylo prováděno jejich měření $\mathrm{v}$ obou zemích, tak jako tomu bylo $\mathrm{v}$ Evropské unii již po delší období za doby trvání její regionální politiky. Jedním z prvních ekonomů, jenž se zabýval inovacemi a jejich podstatnému vlivu na ekonomický cyklus, byl rodák z Vysočiny a ekonom světového významu J. A. Schumpeter. Použil italského pojmu innovare (obnovovat) pro definici faktoru, který odráží proces využívání nových př́ležitostí ve všech činnostech lidského konání a je podstatným činitelem pro ekonomický růst.

V regionalistické literatuře (např. Blažek, 2009, Buček, Rehák, Tvrdoň, 2010) jsou uváděny některé definice toho významného ekonomického faktoru, $\mathrm{z}$ nichž lze rozpoznat různý př́ístup $\mathrm{k}$ dané problematice (Etzkowitz, Leydesdorff, 1997):

- nejobecnejšsí definici inovací popisuje např. Osborn jako schopnost zavést nové do stávajícího systému porovnání ideově-teoretických východisek dokumentů

- Evropská komise definuje inovace jako obnovu a rozšíření škály výrobků, služeb a metod výroby a distribuce, zavedení změn řízení, organizace práce, pracovních podmínek, a kvalifikace pracovní síly

- inovace představuje pro Asociaci inovačního podnikání ČR sérii vědeckých, technických, finančních, organizačních i jiných možností, jejichž cílem je vznik nového či podstatně zdokonaleného produktu (výrobku, technologie, služby), efektivně umístěné na trh

- pro vědecky specializovaného autora na danou problematiku Valentu je inovace jakákoli změna ve výrobním organismu firmy

Jak vidno, není k dispozici jednoznačná definice inovace, ale dá se říci, že jednotlivé regionální inovační strategie budou odrážet výše uvedené spektrum př́stupů $\mathrm{k}$ tomuto pro rozvoj regionu podstatnému jevu. Pro oblast regionální ekonomiky jako celku lze konstatovat, že inovativní jednání platí nejen pro ryze komerční sféru, ale že pojem inovace se vztahuje i na kvalitativní změny $\mathrm{v}$ produktech ve smyslu služeb a procesů veřejného sektoru a tvůrčí zapojení univerzit a výzkumných institucí.

Posilňovaní regionálního rozvoje související s podporou inovací úzce souvisí se znalostní ekonomikou, které růst je založen na schopnosti vytvářet, šírit a užívat nové znalosti (OECD, 1996). Znalostní ekonomika souvisí zejména se změnami v globálním systému, spojeném se zvyšující se rychlosti technologických změn, měnícími se preferencemi zákazníků a zvyšující se konkurencí. Tyto podmínky nutí firmy neustále inovovat a tak si zachovávat a rozšiřovat své pozice na trhu. Tím je ovlivněn i celý regionální rozvoj, kterého konkurenceschopnost souvisí právě se schopností přilákat a udržet firmy a zabezpečit stabilní dlouhodobý růst př́imů obyvatelstva. Koncepty, které poukazují na důležitost systémového př́stupu k inovacím, se orientují na podporu triple helix modelu (Etzkowitz, Leydesdorff, 1997), na podporu ulehčení tvorby, rozšiřování a diseminace inovací. Tyhle koncepty se uplatňují v regionální ekonomice i prostřednictvím regionálních inovačních strategií, které právě vytvářejí koordinovaný př́istup k rozvoji inovací a znalostní ekonomiky na regionální úrovni. Regionální inovační strategie jsou, jako každý strategický dokument, založeny na analýze inovačního systému a podmínek v regionu. Analytická část je podstatnou pro další rozvoj území, které je plánováno prostřednictvím strategické části, kde jsou popsány prioritní oblasti a specifikovány cíle, prostřednictvím kterých se dosáhne změn v prioritních oblastech. Pro úspěšnou implementaci je

\footnotetext{
${ }^{1}$ jedná se o model ve smyslu interagující trojité spirály znázorňující ve svých ramenech soukromý podnikatelský sektor, veřejnou správu a vzdělávací a výzkumný sektor, kde se spirálovitě prolínají jejich zájmy a existují styčné body
} 
klíčové popsat způsob, jakým chceme dosáhnout změn. Způsob je popsán v implementační části, kde se specifikuje akční plán, finanční krytí, způsob monitorování a hodnocení naplnění strategie. V další části článku se věnujeme hodnocení regionálních inovačních strategií i z pohledu sestavování strategií, protože nastavení strategie taky předurčuje úspěšnost její implementace.

Evropská unie vytvořila na hodnocení regiónů v oblasti podpory inovací a dosahování růstu v oblasti znalostní ekonomiky Union Innovation Scoreboard (UIS) ${ }^{2}$ (PRO INNO Europe, 2011). UIS je zaměřen na hodnocení dosahování cílů Evropy 2020 prostř̌ednictvím porovnávacích studií inovačního výkonu EU27 a dalších krajin a analýzou silných a slabých stránek jejich inovačních a vědeckých systémů. UIS je poskládán $\mathrm{z}$ kompozitních indikátorů postavených na třech klíčových dimenzích: aktivátory, aktivity firem a výstupy; a souboru indikátorů. Na základě průměrného inovačního výkonu jsou pak jednotlivé země shlukovány do 4 shluků: inovační lídři, inovační následovatelé, průměrní inovátoři a mírní inovátoři (PRO INNO Europe, 2011). Podle studie PRO INNO Europe (2011) Česká republika a Slovensko spadají do druhého shluku inovačních následovatelů. Krajiny, které jsou považovány za inovační lídry, možno společně charakterizovat silnými stránkami, které se vyznačují zejména silnými národními výzkumnými a inovačními systémy, klíčovou roli podnikatelské aktivity a spolupráci mezi veřejným a soukromým sektorem. Za klíčové oblasti podpory inovací jsou dle tohoto hodnocení považovány tematicky tzv. Aktivátory: Lidské zdroje, Výzkumné systémy, Finance a podpora; dále tzv. Firemni aktivity, k nimž se řadí: Investice do firem, Vazby a podnikání, Intelektuální aktiva; a tzv. Výstupy: Inovátoři a Ekonomické efekty. Hodnocení České a Slovenské republiky podle pozice $\mathrm{z}$ hlediska tématu je možné porovnat $\mathrm{v}$ následující tabulce:

Tab. 1 Pozice ČR a SR v rámci EU 27 v jednotlivých tématech

\begin{tabular}{|l|c|c|c|}
\hline Téma & EU27 prüměr & ČR & SR \\
\hline Lidské zdroje & 18. & 19. & 11. \\
\hline Výzkumné systémy & 13. & 20. & 24. \\
\hline Finance a podpora & 9. & 20. & 24. \\
\hline Investice do firem & 12. & 10. & 26. \\
\hline Vazby a podnikání & 15. & 18. & 24. \\
\hline Intelektuální aktiva & 8. & 22. & 22. \\
\hline Inovátor̆i & 14. & 8. & 18. \\
\hline Ekonomické efekty & 11. & 10. & Zdroj: zpracováno z PRO INNO Europe, 2011
\end{tabular}

\section{Cíl a metodologie}

Cílem předkládaného př́íspěvku bude analýza vybraných inovačních strategií, které jsou vytvářené koncepčně na regionální úrovni jako zásadní víceletý strategický dokument. Tento strategický dokument má za úkol orientovat regionální aktéry ve směru ekonomického rozvoje regionu, založeného na znalostní ekonomice. Měl by podněcovat $\mathrm{k}$ inovativnímu př́stupu k produktům i procesům, napomáhat $\mathrm{k}$ vytváření inovačního milieu $\mathrm{v}$ regionu a zahrnuje opatření jak pro podnikatelskou, tak veřejnosprávní i institucionální znalostní sféru regionu. V další části př́spěvku bude provedena jejich komparace z hlediska zpracování, hlavních témat a forem financování inovací $\mathrm{v}$ regionu a dalších forem podpory inovací.

Pro dosažení cíle bude $\mathrm{z}$ hlediska metodologie práce provedena analýza vybraných regionálních inovačních strategií $\mathrm{v}$ aktuálním období. Z hlediska prostorového pojetí byl vybrán vzorek blízkých moravských a slovenských regionů, jež mají zpracovány tyto strategické dokumenty. Výběr analyzovaných dokumentů byl cíleně zúžen na čtyři regionální inovační strategie z moravských krajů a ze samosprávných krajů západního Slovenska - strategie Moravskoslezského a Jihomoravského kraje, Nitranského samosprávného kraje a Žilinského samosprávného kraje. Z hlediska časového se jedná většinou o období shodné s periodou rozpočtové politiky Evropské unie a periodou kohezní

\footnotetext{
${ }^{2}$ Založené na předcházejícím European Innovation Scoreboard (EIS)
} 
politiky EU, tedy o období 2007-2013. Výjimkou je regionální inovační strategie Moravskoslezského kraje, jež je dlouhodobější s perspektivou roku 2020. Strategie zkoumaných slovenských regionů počínají před tímto termínem, avšak sledované období vždy zahrnují. Analýza vybraných regionálních inovačních strategií by měla sloužit k odhalení předností resp. nedostatků jednotlivých dokumentů, posouzení jejich teoretické i praktické úrovně a kvality zpracování.

Analýza regionálních inovačních strategie bude zahrnovat:

- komparaci z pohledu kvality zpracování strategií, která se zaměřuje na komparaci zpracování jednotlivých částí strategie a propojenosti,

- komparaci z pohledu postavení strategií, kde nás zajímá výběr priorit a opatření jednotlivých krajů,

- komparaci z pohledu využívaní finančních nástrojů a ostatních forem podpory, která bude zahrnovat jejich definici a vztah ke konkrétní regionální inovační strategii; srovnání bude provedeno v přehledné tabulce, shrnující závěry z provedené analýzy.

\section{Výsledky}

V úvodu krátce charakterizujeme pozadí vytváření inovačních strategií v jednotlivých krajích, které vznikaly v různém období, za odlišných podmínek. Dále se zaměřujeme na porovnání jednotlivých částí strategických dokumentů, kde vycházíme z výše uvedené struktury. Hodnotíme tedy naplnění principu participace všech dotknutých stran, zpracování analytické části, strategické a implementační části. V další části se zaměřujeme na komparaci finančních nástrojů využívaných pro rozvoj inovací v krajích.

Moravskoslezský kraj zpracoval svou inovační strategii (dále RIS MSK) vzhledem k neutěšené situaci tohoto regionu $z$ hlediska sociálně-ekonomického vývoje již v roce 2003. Nová verze regionální inovační strategie Moravskoslezského kraje pro roky 2010-2020 obsahuje již detailnější a propracovanější pohled na problematiku inovací v regionu. V úvodu je součástí metodika práce, odkazující se i na zásadní dokumenty Evropské unie, zejména Strategii Evropa 2020, Národní rozvojové priority ČR po roce 2014, Strategii mezinárodní konkurenceschopnosti MPO pro období 2012-2020 a Národní inovační strategii ČR. Nová verze Regionální inovační strategie MSK obsahuje moderní př́stupy $\mathrm{k}$ tvorbě a aplikaci dokumentu takového významu pro region.

Regionální inovační strategie Jihomoravského kraje (dále RIS JMK) je ve své třetí aktualizované verzi zaměřena na zvyšování inovačního potenciálu kraje pro roky 2009-2013. Navazuje na předchozí verze z roku 2001, která byla první svého typu v ČR a druhou verzi, jež byla schválena v roce 2005. Jejich výsledkem bylo vybudování Technologického inkubátoru v Brně a Biotechnologického inkubátoru INBIT, dále zř́zení patentového a licenčního fondu, fondu mikropůjček, vznik dvou klastrů Středoevropského technologického institutu (CEITEC Cluster Bionformatics) a Water Technology Alliance. Na Masarykově univerzitě bylo založeno Centrum pro transfer technologii pro podporu smluvního výzkumu a zakládání spin-off firem a pro podporu mobility $\mathrm{v}$ oblasti studentů pro záměry vědy a výzkumu pak Jihomoravské centrum pro mezinárodní mobilitu. Pro nové období existují 2 klíčové projekty: rozšíření CEITEC a podpora vznikajícího Mezinárodního centra klinického výzkumu $(I C R C)$.

V př́ípade Nitranského kraje, se dle úvodní části jedná o první regionální inovační strategii (dále RIS NSK), zpracovanou ve Slovenské republice již v roce 2004. Stylem zpracování a strukturou se velmi podobá původní regionální inovační strategii Moravskoslezského kraje. Strategii zpracoval soukromý subjekt, VUNAR a.s. Nové Zámky a její zpracování bylo financováno z 5. Rámcového programu EU. Regionální inovační strategie kraje byla zahrnuta jako doplněk do Programu rozvoje Nitranského samosprávného kraje do roku 2013. V současnosti se vypracovává nová regionální inovační strategie, která by měla být zaměřena na nadcházející období.

Regionální inovační strategie Žilinského samosprávného kraje (dále RIS ŽSK) je prezentovaná pod názvem Rámcová stratégia Žilinského regionu pre oblast' inovačného rozvoja a byla vytvořená na 
Žilinské univerzitě v roce 2006. Strategie byla vytvořena na mezinárodní úrovni za podpory partnerů regionu Dolní Rakousko (evropský region excelence), švédského regionu Sodermanland a súčastí Centra pre prenos inovácií v Bratislavě. Ve strategii, která je koncipována na vědeckém základě s využitím zkušeností evropských partnerů, je zdůrazněn princip triple helix, tj. zvýšení inovačního potenciálu regionu na základě spolupráce soukromého sektoru, veřejnosprávního sektoru a univerzit. Ve strategii je rovněž podrobně popsána vazba na základní rozvojové dokumenty - Strategii rozvoje konkurenceschopnosti Slovenska do roku 2010, Národní strategický referenční rámec SR 2007-13. Zajímavou a ve srovnání s ostatními RIS ojedinělou partií dokumentu jsou konstrukce scénářu budoucího vývoje $\mathrm{v}$ oblasti inovací $\mathrm{v}$ ŽSK, jež byly propracovány ve dvou základních variantách $\mathrm{v}$ podobě A. setrvačného scénáře budoucího vývoje inovací a $\mathrm{B}$. žádoucího scénáře budoucího vývoje inovací.

\section{1 Úroveň participace}

Co se týče participace různých zainteresovaných subjektů, v případě RIS MSK se na jejím zpracování podílelo spolu 17 subjektů převážně z veřejného sektoru, poradenství a vědy a výzkumu, v malé míře představitelé významných podnikatelů. Podobně byla zpracována i RIS NSK, i když tady se podílel na jejím zpracování větší počet subjektů (117). Do participace se však jen v malé míre zapojili lokální podnikatelé nebo významní zaměstnavatelé. Žilinský kraj nespecifikoval své pracovní skupiny a Rídicí výbor ve své strategii, ale seznam autorů lze v tomhle př́padě považovat za směrodatný, kde se na zpracování podílelo 21 členů především z oblasti vědy a výzkumu Žilinské univerzity, která je i autorem strategie. Výbor zahrnoval rovněž zahraniční partnery a podnikatele, avšak mezi skupinou absentuje úplně veřejný sektor (samospráva), který má klíčové postavení. Z hlediska participace subjektů, kterých se oblast dotýká, možno hodnotit Jihomoravský kraj jako nejlepší. Participace různých subjektů představovala 105 členů orgánů vytvořených pro př́ípravu strategie a další množství partnerů, kteří participovali na průzkumech (cca 160). Je nutno dodat, že velká část zúčastněných zastupovala soukromý sektor, který představuje klíčového hráče v inovačních procesech ekonomiky.

Celkově však možno zhodnotit, že princip participace jako jeden z klíčových při vytváření strategie byl dodržen, avšak jeho struktura je různá, a ne vždy se podařilo vytvořit triple-helix model spolupráce. Participace subjektů má vliv následně i na nastavení strategie, co se ukáže i z dalšího porovnání.

\subsection{Zhodnocení analytické části}

RIS MSK (2010) obsahuje situační analýzu, která postihuje stav inovačního podnikání v kraji, analýzu institucionální infrastruktury $\mathrm{v}$ regionu a rovněž popisuje existující nástroje podpory zvyšování inovačního potenciálu regionu. Následuje poměrně obsáhlá SWOT analýza potenciálu př́ležitostí a hrozeb pro rozvoj inovačních aktivit v Moravskoslezském kraji, avšak bez detailnějšího rozboru obecných i specifických vlastností regionu charakterizujících ekonomický, sociální a demografický vývoj a přírodní podmínky s ohledem na podporu inovací.

Na rozdíl od ostatních strategií, RIS JMK neobsahuje teoretické zdůvodnění předkládané strategie, pouze stručné zhodnocení koncepční návaznosti na předešlé verze, v úvodu rovněž předkládá schéma řídící struktury pro její realizaci. $\mathrm{V}$ další části je provedena srovnávací analýza regionální výkonnosti (regionální benchmarking) ohledně určení pozice Jihomoravského kraje v rámci ostatních regionů Evropské unie. Součástí strategie je i velmi podrobná situační analýza firemní sféry Jihomoravského kraje včetně kvantitativního průzkumu dle odvětví a následně kvalitativního průzkumu na základě ř́zeného rozhovoru pro 160 vybraných firem. V průzkumu byly vedle obecných problému i zmíněny specifické problémy firem, zejména týkající se poradenství a spolupráce s oblastí vědy a výzkumu. Následuje přehledná SWOT analýza, jež obsahuje shrnutí poznatků z provedených analýz a zahrnuje prostředí všech komponentů regionálního inovačního prostoru - tj. vědecko-výzkumnou sféru, veřejnou správu a firemní prostředí na základě tzv. triple-helix modelu. 
RIS NSK v úvodní části obsahuje prostorovou analýzu regionu s uvedením základních ekonomických, sociálních, demografických a geograficko-přírodních parametrů, jež se u předešle analyzovaných RIS nevyskytují, resp. vyskytují ve velmi zúžené podobě. Následuje analýza inovačního potenciálu kraje, provedená na základě kvalitativního dotazníkového šetření zpracovatele - ve struktuře analýza inovačních potřeb malých a středních podniků, analýza technologické nabídky v regionu a analýza financovaní inovací v regionu (Regionální inovační strategie MSK, 2012). V následující části týkající se tvorby vlastní inovační strategie jsou popsány trendy, které by měly respektovat cíle inovační strategie - budování informační společnosti, podpora začínajících podnikatelů, vyžívání alternativních zdrojů energie, ochrana životního prostředí, podpora inovací, budování partnerství a sítí, rozvoj lidských zdrojů; odkazuje se zde na obecné směry politik EU a jsou definovány na rozdíl od předešle analyzovaných RIS prŕliš obecně. Tato část obsahuje i stručnou SWOT analýzu kraje, která se neliší od předešle podaných SWOT u moravských RIS.

RIS ŽSK byla vytvořena na základě provedených analýz, jež vedly $\mathrm{k}$ určení inovační charakteristiky regionu a které předznamenaly charakter RIS. Tyto vědecké analýzy zahrnují analýzu inovačních potřeb podnikatelských subjektů v ŽSK, analýzu inovační nabídky institucí v ŽSK, SWOT analýzu s navrženými způsoby na zvýraznění silných stránek, odstranění slabých stránek, využití př́iležitostí a eliminaci hrozeb, predikci inovačního vývoje metodou Regional Technology Foresight a regionální benchmarking zaměřený na nalezení nejlepších zkušeností $\mathrm{v}$ oblasti zavádění inovací u vybraných evropských regionů.

Když porovnáváme zpracování analytické části, je možné zhodnotit, že všechny strategie se více méně zaměřily při analýze na hodnocení inovačního potenciálu, a tedy hodnotily inovační výkonnost, stav vědy a výzkumu, strukturu firem z pohledu tvorby inovačního prostředí a kvalitu lidských zdrojủ. Je potřebné ocenit (v prrípadě Nitranského a Jihomoravského kraje), že při př́pravě strategií byly použity nejen sekundární údaje, ale taky primární údaje. Zajímavým je opět př́stup Jihomoravského kraje, který se $\mathrm{v}$ analýze soustředil v první řadě na identifikaci klíčových odvětví kraje, a pak v rámci každého odvětví analyzoval jednotlivé aspekty jako lidské zdroje, strukturu firem a specifika firem, věda a výzkum, využití technologií apod. Žilinský kraj zas využil metodu Regional Technology Foresight na předpovídání scénářu pro budoucí inovační vývoj. Nitranský kraj se ve větší míře zaměřil na všeobecnou charakteristiku kraje a pak na výsledky dotazníkového šetření určeného firmám (50 firem) a výzkumným institucím. Absentuje však hlubší analýza zaměřena na inovační potenciál a lidské zdroje a výsledky dotazníkového šetření není možné zevšeobecnit při dané vzorce.

\subsection{Zaměření strategií krajů}

Tab. 2 Porovnání prioritních témat strategií

\begin{tabular}{|c|c|c|c|}
\hline MSK & JMK & NSK & ŽSK \\
\hline 1 transfer technologií & 1. transfer technologií & $\begin{array}{l}\text { 1. vytváření } \\
\text { prostř̌edí a a } \\
\text { inovační osvěta }\end{array}$ & $\begin{array}{l}\text { 1. inovační politika a } \\
\text { kultura }\end{array}$ \\
\hline 2 lidské zdroje & $\begin{array}{l}\text { 2. poradenství } \quad \text { a } \\
\text { služby pro firmy }\end{array}$ & $\begin{array}{l}2 . \quad \text { Šíření poznatků a } \\
\text { vzdělávání v oblasti inovací a } \\
\text { tvořivosti }\end{array}$ & $\begin{array}{l}\text { 2. spolupráce pri } \\
\text { inovacích }\end{array}$ \\
\hline 3 internacionalizace & 3. lidské zdroje & $\begin{array}{l}\text { 3. podpora inovačního } \\
\text { procesu }\end{array}$ & $\begin{array}{l}\text { 3. infrastruk. podpora } \\
\text { inovací }\end{array}$ \\
\hline $\begin{array}{lcc}4 & \text { koordinace } & \text { a } \\
\text { implementace RIS } & \end{array}$ & 4. internacionalizace & $\begin{array}{l}\text { 4. zabezpečení podpůrného } \\
\text { mechanizmu pro financování } \\
\text { inovací }\end{array}$ & $\begin{array}{l}\text { 4. finanční podpora } \\
\text { inovací }\end{array}$ \\
\hline & & & $\begin{array}{l}\text { 5. znalostní základna } \\
\text { inovací }\end{array}$ \\
\hline
\end{tabular}

Zdroj: vlastni zpracování

Když porovnáváme jednotlivé strategie krajů, u tř́ regionů můžeme sledovat podobnou strukturu, kde je definována vize, strategický cíl, prioritní oblasti (nebo osy), a pak specifické cíle (nebo opatření). Nitranský region má definovány prioritní oblasti a pak návrhy projektů, takže je vynechána úroveň 
operačních cílů, které by blíže popsaly, směr intervencí u každé priority. Prioritní oblasti Moravskoslezského a Jihomoravského kraje jsou téměř stejné: Transfer technologií, Lidské zdroje a Internacionalizace (Jihomoravský kraj má navíc prioritu Poradenství a služby pro firmy a Moravskoslezský kraj zase prioritu Koordinace a implementace RIS).

Ve strategii RIS JMK je zmíněn základní cíl - stát se v roce 2013 nejvíce inovativním regionem v rámci Ceské republiky a to na základě zjištění pomocí zkonstruovaného inovačního indexu, jenž je vypočítáván na základě metodiky European Regional Innovation Scoreboard (PRO INNO Europe, 2011). V př́ípadě JMK je zajímavá specializace strategie na odvětví strojírenství, elektrotechniky, informační a komunikační technologie a „life sciences“ (heterogenní odvětví průmyslu provázaná s aplikovaným výzkumem).

U Moravskoslezského jakož i u Žilinského kraje je možné vidět výraznou orientaci na podporu spolupráce $\mathrm{VaV}$, co může mít souvis i s výraznou participací krajských univerzit na zpracovávání strategie. Moravskoslezský kraj ve strategii klade důraz na realizaci smluvního výzkumu v obou univerzitách v regionu, tj. Vysoké školy báňské - Technické univerzity Ostrava a Slezské univerzity Opava, které by měly pro privátní podnikatelský sektor sloužit jako významný faktor vytváření znalostní ekonomiky v regionu. V př́ípadě RIS NSK, i když má definovány základní strategické cíle: mobilizace a rozvoj inovačního potenciálu NSK, rozvoj lidského potenciálu a podpora kreativity, vybudování infrastruktury regionální inovační a vzdělávací sítě a vybudování regionální inovační základny pro konkurenceschopnost podnikatelského sektoru regionu, definované prioritní oblasti a jednotlivé projekty neumožňují naplnění těchto cílů, protože priority jsou definovány velmi podobně a jednotlivé aktivity a činnosti jsou definovány spíše deklarativně.

Při hodnocení zaměření prioritních témat jednotlivých strategií vycházíme z UIS, kde jsou definovány klíčové oblasti podpory do oblastí aktivátorů, firemních aktivit a výsledků. V tabulce 3 je krátké zhodnocení, které specifické cíle (v př́ípadě Nitranského kraje priority) se týkají které oblasti. Jak je možné vidět, všechny kraje se zaměřují především na podporu vědy a výzkumu, spolupráce mezi vědou a výzkumem a firmami, podporou firemních aktivit.

Tab. 3 Zaměrení specifických cílů strategii podle UIS

\begin{tabular}{|l|c|c|c|c|}
\hline & MSK & JMK & NSK & ŽSK \\
\hline Aktivátory & 7 & 10 & 3 & 5 \\
\hline Firemní aktivity & 2 & 5 & 1 & 6 \\
\hline Výsledky & 1 & \multicolumn{4}{c|}{ Zdroj: vlastní zpracování }
\end{tabular}

\subsection{Implementační rámec}

Implementační rámec $\mathrm{u}$ všech strategií zahrnuje akční plán, $\mathrm{v}$ rámci kterého jsou blíže popsány projekty k dosáhnutí naplnění strategie, dále monitorovací a hodnotící rámec jako i institucionální zodpovědnost. V implementačním rámci je možné vidět konkretizaci kroků, které daný kraj zamýšlí a způsob jejich realizace. Jak možno vidět z jednotlivých strategií, tak ve velké míře závisí od složení pracovní skupiny, která se podílí na zpracování strategie.

Moravskoslezský kraj definuje při každém specifickém cíli projekty, které by se měly realizovat spolu $\mathrm{s}$ indikátory monitorování a hodnocení ${ }^{3}$. Jednotlivé projekty jsou vždy v popisu charakterizovány

\footnotetext{
${ }^{3}$ V oblasti Transfer technologii jde o tyto projekty: Podpora spolupráce klastrů ve VaV, Podpora firem v MSK na tvorbu pracovních míst ve VaV, Rozvoj a stabilizace transferu technologií univerzit, Podpora VaV v kraji (inovační vouchery), Aktivní marketing výzkumných center, Podpora v poradenství při zakládání spin-offs a inovativních starts-up firem, Fond mikropůjček, Inovativní hub pro studenty univerzit v MSK, Patentový fond, Workshopy s investory rizikového kapitálu k financování podnikatelských inovativních záměrů, Odborné workshopy na témata $\mathrm{VaV}$; v oblasti Podpory lidských zdrojů jde o projekty: Podpora vědy a výzkumu v MSK, Př́íležitost pro mladé výzkumníky, Program podpory mobility ve znalostních institucích (sít’ EURAXESS);
} 
záměrem, garantem, finančními náklady, zdroji financování a rámcovým harmonogramem realizace. Dále je v rámci téhle části popsán institucionální rámec, kde je stanovena zodpovědnost za úkoly na ř́́dící a výkonné úrovni. Podobně je koncipován i implementační rámec RIS JMK, kde jsou při každém cíli navrženy projekty, které jsou rozpracovány ${ }^{4}$ Implementační rámec zahrnuje rovněž návrh implementačních a monitorovacích opatření a vazbu na nadřazené strategické dokumenty Jihomoravského kraje a města Brna.

V př́ípadě RIS NSK jsou návrhy projektư ${ }^{5}$ stanoveny př́mo pro priority, zaměřují se na zvyšování kapacity získaní finančních zdrojů mimo regionu a na propagaci a budování spolupráce, tedy na roli veřejného sektoru v triple helix modelu. Zdroj financování je jednotně uváděn jako sektorový operační program či státní rozpočet, výjimečně privátní kapitál, zcela chybí rizikový kapitál z oblasti jointventures nebo business angels. Aktivity jsou směrovány více do veřejné institucionální sféry; mezi konkretizované aktivity směřované na podnikatelskou sféru lze zařadit jedině zř́izení regionálních podnikatelských klubů a vytvoření regionálního inovačního fondu.

Žilinský kraj se zaměřil na oblasti inovační politiky a kultury, spolupráce při inovacích, infrastrukturní podpory inovací, finanční podpory inovací a vybudování znalostní základny inovací. Obdobně jako ve vyspělých inovačních strategiích moravských krajů jsou zde již navrženy jednotlivé projekty, jejichž realizace by měla přiblížit cíle inovační strategie ${ }^{6}$. Strategie Žilinského kraje očekává 3 výsledky: transfer nejnovějších technologií do průmyslu, vytváření sofistikovaných pracovních prŕležitostí s vysokou kvalifikací a rozvoj malého a středního podnikání včetně tréninkových procesů a prrístupu k financování. V rámci zabezpečení udržitelnosti navrhovaných projektů byly vytvořeny pilotní programy, realizované již v roce 2007 a zaměřené na vytvoření systému veřejné finanční podpory inovací, tvorbu inovační kultury v regionu a vytvoření interaktivního inovačního portálu regionu a organizaci inovačních workshopů pro podnikatele.

v oblasti Internacionalizace jde o projekty: Brockerage Events (prezentační akce), One-stop-shop centrum (kontaktní centrum podpory mezinárodní spolupráce), Technology foresight - identifikace variant vývoje klíčových odvětví MSK

${ }^{4}$ V oblasti Transfer technologii: TT point (vytvoření sítě podporující transfer technologií), Inovační vouchery (spolupráce univerzit a firem na menších inovačních projektech), Technology Accelerator Fund (fond pro ověření technologií), Zřízení podnikatelských inkubátorů a vědecko-technických parků, Rozvoj specializovaných služeb pro inovativní firmy,, Seed Fund (fond na podporu inovativního podnikání, pořádání finančních fór), Fond mikropůjček, Patentní a licenční fond, Vznik inovačních center (prvním v roce 2008 Microsoft Inovační centrum-MSIC); v oblasti Lidské zdroje: Vědecko-technologické muzeum v Brně, Vzdělávání a rozvoj talentované mládež v JMK, Stipendia pro talentované doktorandy, SoMoPro jihomoravský program pro špičkové vědce, Centrum mobility EURAXESS (v rámci sítě financované z FRP 6), Byty pro zahraniční vědce, Podnikatelská rada Jihomoravského inovačního centra (Board CEO); v oblasti Internacionalizace: Odvětvové konference (Gate2Biotec, ICT most-INVEX), Brokerage Events (mise do technology hot spots, prezentace inovační činnosti), Mezinárodní dům (služby pro segment kreativní cizinci), Mezinárodní střední škola

${ }^{5}$ Zvyšovat' povedomie o nevyhnutnosti a potrebe inovácií, Vytvorit' pravidlá, systém, program a iniciovat' nové legislatívne normy pre podporu inovácií na regionálnej úrovni, Získat' MSP k účasti v inovačnom procese prostredníctvom informačnej kampane, Vytvárat' informačné body a centrá prvého kontaktu, Zabezpečit rovnomerné a priestorovo vyvážené využívanie možností ponúkaných štrukturálnymi fondy a inými EU programami, vybudovat' regionálnu inštitúciu zameranú na tvorivost' a inovácie, organizovat' vzdelávacie aktivity, semináre, tréningy šité na mieru MSP, Zabezpečit' výmenu skúseností a informácií medzi MSP, výskumnými inštitúciami, univerzitami a podpornými inštitúciami, Organizovat regionálne a medzinárodné prezentačné dni pokrokových technológií a výsledkov výskumu a vývoja (VaV), Vytvorit' Regionálne centrum pre rozvoj tvorivosti a inovácií, Organizovat' pomoc pre MSP a regionálne inštitúcie pri vypracovaní projektov na získanie prostriedkov z domácich a európskych fondov, Zabezpečit' aplikácie európskych a svetových priorít rozvoja $\mathrm{v}$ regionálnej inovačnej činnosti a podnikaní, Iniciovat' vznik regionálnych podnikatel'ských klubov, Rozvinút' regionálnu spoluprácu medzi MSP a inovačnými i podpornými inštitúciami, Plne využit' regionálne i mimoregionálne výskumnovývojové kapacity univerzít a VaV inštitúcí́, Vytvorit' mechanizmus systematického čerpania ŠF, Š́rit' informácie o možnostiach financovania inovácií a manažment financovania inovácií, Podporovat’ aktivity vedúce k zviditel’ňovaniu regiónu, Prilákanie investorov, Prilákanie inštitúcií podporujúcich financovanie inovácií, Zriadit' regionálny inovačný fond

${ }^{6}$ Projekty jak: Klastry a partnerství (spolupráce a růst mezinárodní konkurenceschopnosti firem), Univerzitní brokerské centrum (klientský systém práce na univerzitách pro firmy), Regionální inovační portál (transfer znalostí a informací pro regionální subjekty), Kompetenční a výzkumná centra (zapojení fïem do mezinárodního VaV), Tvorba inovační infrastruktury (transfer technologií) Vzdělávací, poradenská a tréninková centra (vzdělávání pro praxi, služby pro MSP), Regionální inovační fond pro segment MSP 


\subsection{Komparace aktivit a finančních nástrojů regionálních inovačních strategií.}

Na základě analýzy regionálních inovačních strategií a jejich komparaci a na základě komparace odborných zdrojů v oblasti teorie inovací ve vztahu k regionu lze definovat tyto základní aktivity a nástroje podpory:

Klastry - seskupení spolupracujících firem a institucí veřejného sektoru v daném oboru Centra excelence - špičková výzkumná a vývojová pracoviště se silným inovačním potenciálem Profesorská židle - financování stálého či rotujícího zahraničního experta v dané instituci Klub ex-patriotů - využití znalostního a sociálního kapitálu úspěšných rodáků

Start-up granty - pro úspěšné doktorandy a podpora zakládání absolventských firem - podpora rozvoje inovativního podnikání absolventů vysokých škol

Inovační vouchery - poukázky na finanční prostředky pro firmy na oblast výzkumu a inovací od vybraných výzkumných institucí (např. JMK 150 tis. Kč, kofinancování firem 25\% hodnoty voucheru; existuje opačná možnost poskytování inovačním voucher výzkumným institucím a vysokým školám.

Internetový inovačni portál - komplexní webové stránky (one-shop-stop) sdružující nabídku a poptávku znalostně náročných služeb, interaktivně reagující na dotazy a podněty firem a institucí a univerzit (TT point)

Technology foresight - usnadnění orientace MSP v technologickém vývoji a podpora využívání nových technologií

Technology accelerator fund - finanční nástroj pro ověřování technologických inovací pomocí tzv. proof-of-concept což je dotace na ověření technologie či produktu, kde př́jemcem je vývojová instituce či ověřovatel technologie nebo držitel licence pro komerční využití (ve světě 2-4 mil. Kč)

Market inteligence - usnadnění orientace MSP v orientaci na zahraničních i domácích trzích a nalezení konkurenční výhody

Brockerage events - obchodní a informační mise do blue-chip firem a technologických center v zahraničí

Seed fondy - státem podporované investice rizikového kapitálu jsou určeny především začínajícím podnikatelům, kteří hledají zárodečný nebo startovní kapitál k rozjezdu své firmy založené na nových nápadech a inovacích namísto obvyklých dotací resp. bankovních produktů či investic venture kapitálových fondů

Patentní a licenční fondy - finanční zdroje na podporu ochrany duševního vlastnictví

Business angels - investoři do MSP z řad velkých korporací

Workshopy s joint-venture capital - semináře s investory z řad rizikového kapitálu

Brokerské centrum - univerztní centrum pro klientelu z řad MSP z hlediska šíření poznatků z vědy

Tab. 4 Komparace RIS z hlediska finančních nástrojů a podpor inovací

\begin{tabular}{|l|l|l|l|l|}
\hline \multicolumn{1}{|c|}{ Region } & \multicolumn{1}{c|}{ MSK } & \multicolumn{1}{c|}{ JMK } & \multicolumn{1}{c|}{ NSK } & ŽSK \\
\hline $\begin{array}{l}\text { Seed fund } \\
\text { Patentní } \\
\text { licenční fond }\end{array}$ & ano & ano & ne & ne \\
\hline $\begin{array}{l}\text { Fond } \\
\text { mikropuijček }\end{array}$ & ano & ano & ano & ano \\
\hline $\begin{array}{l}\text { Ostatní } \\
\text { podpora }\end{array}$ & $\begin{array}{l}\text { Klastry } \\
\text { Inovativní hub } \\
\text { Inovační vouchery } \\
\text { Technologe events } \\
\text { foresight } \\
\text { Inovační portál } \\
\text { Workshopy JVC }\end{array}$ & $\begin{array}{l}\text { Klastry } \\
\text { Inovativní hub } \\
\text { Inovační vouchery } \\
\text { Brockerage events } \\
\text { Technology } \\
\text { foresight } \\
\text { Kreativní cizinci } \\
\text { Inovační portál } \\
\text { Workshopy JVC }\end{array}$ & $\begin{array}{l}\text { Inovační portál } \\
\text { Technology } \\
\text { foresight }\end{array}$ & $\begin{array}{l}\text { Klastry } \\
\text { Regionální } \\
\text { inovační } \\
\text { Benchmarking } \\
\text { Brokerské centrum } \\
\text { Inovační portál } \\
\text { Technology } \\
\text { foresight }\end{array}$ \\
\hline
\end{tabular}




\section{Závěr}

Současné regionální inovační strategie odrážejí vliv neoinstitucionalistické teorie $\mathrm{v}$ oblasti endogenního rozvoje regionů, úlohy jednotlivých aktérů a lídrů v rozvoji regionu a v důrazu na znalostní ekonomiku a úlohu znalostního kapitálu jako důležitého výrobního faktoru je oblast inovací a jejich vlivu na rozvoj regionální ekonomiky. Analýza regionálních inovačních strategií přináší zajímavý a širokospektrální pohled na problematiku existence inovačního prostoru, budování jeho struktury a institucí ve smyslu hmotném i ideovém. $\mathrm{K}$ analýze byly vybrány nepř́lilš vzdálené regiony Moravy a Slovenska, které jsou vcelku rozdílného charakteru - nesourodý a odlehlý Moravskoslezský kraj s velkými strukturálními, sociálními, environmentálními a infrastrukturními problémy, zemědělsko-průmyslově orientovaný Jihomoravský kraj s výbornou geografickou polohou $\mathrm{v}$ trojúhelníku Brno, Vídeň, Bratislava s výrazným univerzitním a průmyslovým centrem v Brně a cílem stát se nejvíce inovativním regionem v ČR. Slovenské regiony reprezentuje charakterem výrazně zemědělský Nitranský samosprávný kraj s významným univerzitním centrem Nitrou a převážně horský Žilinský kraj, který sousedí s Moravskoslezským krajem a má jako on podobné strukturální problémy, je obdobně nesourodý se několika průmyslovými centry, ale je při své geografické poloze v Pováží významným infrastrukturním uzlem $\mathrm{v}$ rámci Slovenska se silně vytvářeným prostředím pro rozvoj inovací (díky existenci silné univerzity a hospodářského rozvoje v Žilinském okrese v oblasti automobilového průmyslu). Vybrané regiony spojuje záměr zvyšování inovačního potenciálu a zvýšení konkurenceschopnosti v rámci globální soutěže. $Z$ hlediska časového jsou regionální inovační strategie zpracovány rovněž velmi nesourodě, avšak vždy je reprezentováno aktuální období 20072013, které se kryje s programovacím obdobím kohezní politiky i s finanční perspektivou EU. Ve všech zpracovaných at' starších či aktualizovaných verzích RIS je totiž patrná vazba na financování ze strukturálních i komunitárních programů EU. Vyčnívá zde výrazně RIS Moravskoslezského kraje, jež je zpracována od roku 2010 s výhledem do roku 2020, ač je otázkou, na kolik lze v současné turbulentní době reálně koncipovat své záměry na tak poměrně vzdálenou dobu. Nejstarší zpracovanou RIS má Jihomoravský kraj z roku 2001, jeho verze je však aktualizovaná.

Pokud bychom měli porovnat jednotlivé regionální inovační strategie (bez hodnocení jejich dopadu, což není předmětem jejich analýzy), pak RIS Nitranského samosprávného kraje, vytvořená v roce 2004, nebyla aktualizována a poskytuje často pouze obecné formulace a deklarativní cíle. Neobsahuje $\mathrm{z}$ tohoto důvodu aktuální koncepce a moderní prístupy k zvyšování inovačního potenciálu regionu (důraz na spin-offs a start-ups firmy a podnikatelské inovace vůbec, financování rizikovým kapitálem a business angels, zapojování kreativních cizinců, provádění regionálního inovačního benchmarkingu, brokerage events apod.). Deklarované cíle a záměry, i když jsou velmi detailně zpracovány, nejsou dovedeny do úrovně návrhu jednotlivých projektů. Naopak toto vše obsahuje RIS Žilinského samosprávného kraje, kde výrazný vliv při jejím zpracování mělo skloubení odborného vedení Žilinské univerzity a mezinárodní podpory a praktické zkušenosti mezinárodních partnerů - regionu evropské excelence Dolní Rakousko a švédského regionu Sodermanland. Obdobnou úroveň má aktualizovaná verze RIS Moravskoslezského kraje (stará verze měla podobnou úroveň jako RIS Nitranského samosprávného kraje), jenž využívá silného potenciálů 3 univerzit - UTB a VŠB Ostrava a Slezské univerzity Opava. Rovněž její priority a cíle jsou dovedeny do konkrétních projektů a obsahují moderní prístupy zejména ve vztahu k inovativnímu podnikání a budování inovačních sítí.

Nejvyšší úroveň má dle našeho názoru, vytvořeného na základě provedených analýz, RIS Jihomoravského kraje, která ve své již třetí verzi může rovněž doložit výrazné mezinárodní úspěchy z realizace velkých projektů Středoevropského technologického institutu CEITEC a mezinárodního centra klinických výzkumů ICRC. Je zde patrný vliv velmi úspěšné spolupráce v rámci triplex helixvysoká úroveň podpory ze strany veřejné správy, reprezentované zejména krajskou správou a statutárním městem Brnem a jejich institucemi a agenturami, aktivní zapojení podnikatelské sféry z řad velkých korporací i malých a středních firem a vliv úspěšné teoretické i výzkumné činnosti 3 významných brněnských univerzit - Masarykovy univerzity, Vysokého učení technického a Mendlovy univerzity. 
Na závěr provedené analýzy regionálních inovačních strategií lze konstatovat, že její úroveň a kvalita zpracování má souvislost $\mathrm{s}$ postojem regionu k zvyšování inovačního potenciálu regionu a inovacím všeobecně ve vztahu k jeho ekonomickému rozvoji a rovněž odráží kvalitu vztahů mezi jednotlivými aktéry triple-helix (tj. veřejné správy, podnikatelského segmentu a univerzit a výzkumné sféry) ve sledovaném regionu.

\section{Literatura}

[1] BUČEK, M. - REHÁK, ̌̌. - TVRDOŇ, J. Regionálna ekonómia a politika. Bratislava: Iura Edition, 2010. 269 s. ISBN 978-80-8078-362-4

[2] ETZKOWITZ, H., LEYDESDORFF, L. Universities and the Global Knowledge Economy: A Triple Helix of University-Industry-Government Relations. London: Cassel Academic, 1997.

[3] Nitriansky samosprávny kraj [online]. 2004 Regionálna inovačná stratégia. [cit. 2013-4-08]. Dostupné z: <http://www.unsk.sk/files/regionalny/rissk_broz_sk.pdf $>$.

[4] OECD. The Knowledge Based Economy. Paris: OECD, 1996.

[5] PRO INNO EUROPE. [online]. 2011. Regional Innovation Scorebboard. [cit. 2013-3-28] Dostupné z: <http://www.proinno-europe.eu/page/regional-innovation-scoreboard>.

[6] Regionálni inovačni strategie Moravskoslezského kraje [online]. 2003 [cit. 2013-3-28]. Dostupné z: $<$ http://www.kr-moravskoslezsky.cz/zip/rr_ristra.pdf $>$.

[7] Regionální inovačni strategie Moravskoslezského kraje. Návrhová část. [online]. 2012 [cit. 2013-3-28]. Dostupné $\quad$ z: $\quad<$ http://verejna-sprava.krmoravskoslezsky.cz/zip/ris_msk_2010_2020.pdf >.

[8] Regionální inovačni strategie Moravskoslezského kraje. Seznam rozvojových projektů RIS Moravskoslezského kraje na léta 2012-2020. [online]. 2012 [cit. 2013-3-28]. Dostupné z $<\mathrm{http}: / /$ verejna-sprava.kr-moravskoslezsky.cz/zip/RIS_MSK-akt_Priloha_1.pdf>.

[9] Regionální inovačni strategie Moravskoslezského kraje. SWOT̄ analýza. [online]. 2012 [cit. 2013-4-08]. Dostupné z: <http://verejna-sprava.kr-moravskoslezsky.cz/zip/RIS_MSKakt_SWOT.pdf $>$.

[10] Regionální inovační strategie Jihomoravského kraje [online]. 2009 [cit. 2013-4-08]. Dostupné z: <http://www.kr-jihomoravsky.cz/Default.aspx?PubID=123753\&TypeID=7>.

[11] STEJSKAL, J., Kovárník, J. Regionální politika a její nástroje. 1. vydání. Praha, nakladatelství Portál, 2009. ISBN 978-80-7367-588-2

[12] Žilinská inovačná politika [online]. 2004. Regionálna inovačná stratégia. [cit. 2013-4-08] Dostupné z: $<$ http://www.zip.utc.sk/index.php?id=1>.

Př́spěvek byl zpracován v rámci grantu Interní grantové soutěže VŠPJ č. VSPJ/01266/2013-KR „Finanční programy na podporu inovací v regionu“ 